\title{
MENGUKUR LOYALITAS PELANGGAN MELALUI CITRA TOKO DAN KEPERCAYAAN PELANGGAN DI TOKO RETAIL
}

\author{
Hartiwi Prabowo ${ }^{1}$; Viona $^{2}$ \\ ${ }^{1,2}$ Jurusan Manajemen, Fakultas Ekonomi dan Bisnis,Universitas Bina Nusantara \\ Jln. K.H. Syahdan No. 9, Palmerah, Jkarta Barat 11480 \\ hartiwi2200@binus.ac.id
}

\begin{abstract}
An automobile spare parts shop at first having its sales increased. But, in 2008 the store experienced a significant decline in sales, so that the purpose of this study was to determine how much influence store image and customer trust on customer loyalty. This type of research is associative descriptive research. Data collection is conducted using questionnaires using Likert scales to 100 shop. Technical analysis is conducted using several techniques, which are Test Validity, Test Reliability, Test Normality, and Path Analysis. Results show that customer loyalty is influenced by greater consumer confidence than the image of the store. Therefore, PT Sloka Kencana Abadi must continue to improve the image of his shop by looking for a more strategic location making it easier to attract new customers, set prices according to the quality of the product and prices set by the competitor, maintain the quality of the product in the sense that the product is durable and free from damage, providing many choice of products making it easier for consumers to find the required product, and maintain these.
\end{abstract}

Keywords: customer loyalty, store image, customer trust

\begin{abstract}
ABSTRAK
Toko sparepart mobil pada mulanya mengalami peningkatan penjualan. Namun, pada tahun 2008 toko mengalami penurunan penjualan yang cukup signifikan, maka tujuan penelitian ini adalah mengetahui seberapa besar pengaruh citra toko dan kepercayaan pelanggan terhadap loyalitas pelanggan. Jenis penelitian yang digunakan adalah penelitian deskiptif asosiatif. Teknik pengumpulan data dengan menggunakan kuesioner ke 100 pelanggan toko, dan model skala kuesioner adalah skala Likert. Teknik metode analisis menggunakan beberapa teknik, yaitu Uji Validitas, Uji Reliabilitas, Uji Normalitas dan Analisis Jalur. Hasil analisis menunjukan bahwa loyalitas pelanggan lebih besar dipengaruhi oleh kepercayaan pelanggan dibandingkan dengan citra toko, maka PT Sloka Kencana Abadi harus terus meningkatkan citra tokonya dengan cara mencari lokasi yang lebih strategis sehingga lebih mudah untuk menarik konsumen baru, menetapkan harga yang sesuai dengan mutu dari produk dan berdasarkan harga yang ditetapkan oleh para pesaing, menjaga kualitas dari produk dalam arti produk tahan lama dan bebas dari kerusakkan, memberikan pilihan produk yang banyak sehingga memudahkan konsumen untuk mencari produk yang dibutuhkan serta mempertahankan.
\end{abstract}

Kata kunci: loyalitas pelanggan, citra toko, kepercayaan pelanggan 


\section{PENDAHULUAN}

CAC Nielsen melakukan studi pada tahun 2000 mengenai atribut yang menjadi alasan konsumen di Inggris dalam memilih gerai menemukan bahwa atribut yang paling penting diantaranya adalah good value for money sebesar $18.8 \%$ responden, lokasi nyaman $17.7 \%$, kemudahan parkir $16.4 \%$, harga rendah $14.5 \%$, banyak pilihan $11.6 \%$, gerai bersih dan tertata $5.4 \%$, staf yang membantu sebesar $1.1 \%$, dan sisanya faktor lain (Ma'ruf, 2006). Citra toko merupakan salah satu alat yang terpenting bagi retailer untuk menarik dan memenuhi kepuasan konsumen. Konsumen menilai sebuah toko berdasarkan pengalaman mereka atas toko. Hasilnya, beberapa toko akan menetap dalam benak konsumen apabila ia merasa puas akan toko tersebut sementara toko yang lain tidak akan pernah dipertimbangkan sama sekali. Jika sebuah toko mempunyai citra yang positif di mata konsumen, maka konsumen akan akan timbul rasa percaya terhadap toko tersebut. Jika kepercayaan konsumen diperoleh, maka akan berakibat pada munculnya loyalitas kepada perusahaan (Shabazz, Abu AnNagary, 2008).

PT Sloka Kencana Abadi adalah salah satu perusahaan yang berlokasi di Jakarta Barat,lebih tepatnya di Jalan Lapangan Bola No.38, Kebon Jeruk. Perusahaan tersebut telah berdiri sejak 14 Maret 2005, bergerak di bidang otomotif, khususnya untuk penjualan sparepart mobil merek KIA, Toyota, Hyundai, Honda, dan Mitsubisi. Menurut sumber yang peneliti dapat, selama 4 tahun sejak berdirinya PT Sloka Kencana Abadi, perusahaan tersebut mengalami peningkatan penjualan, tetapi di tahun 2008 mengalami penurunan.

Tabel 1 Perkembangan Penjualan di PT Sloka Kencana Abadi Tahun 2005-2008

\begin{tabular}{ccccc}
\hline Tahun & $\mathbf{2 0 0 5}$ & $\mathbf{2 0 0 6}$ & $\mathbf{2 0 0 7}$ & $\mathbf{2 0 0 8}$ \\
\hline Total Penjualan & Rp 7.827.770.390 & Rp 13.712.874.010 & Rp 15.467.956.084 & Rp. 14.398.597.495 \\
\hline \multicolumn{5}{c}{ Sumber: Data Penjualan PT Sloka Kencana Abadi } \\
\end{tabular}

Menanggapi intensitas persaingan yang semakin ketat karena banyaknya perusahaan yang bergerak dalam dunia otomotif, PT Sloka Kencana Abadi perlu meninjau kembali variabel-variabel retailing mix yang mereka telah terapkan, apakah telah membawa pelanggan untuk melakukan kunjungan, dan pembelian kembali atau belum. Tujuan penelitian ini adalah untuk mengetahui seberapa besar pengaruh citra toko dan kepercayaan pelanggan terhadap loyalitas pelanggan.

Beberapa penelitian sebelumnya; Priyono (2008), setiap pemasar mendambakan loyalitas pelanggan yang tinggi dan sekuat tenaga berusaha mempertahankannya. Salah satu upaya yang dilakukan untuk menimbulkan loyalitas pada pelanggan, yaitu dengan menciptakan citra toko yang positif. Berdasarkan pendapat Andreassen dan lindestad (1998) dalam Hawkins et al. (2004:626), menyatakan "Adanya hubungan antara citra toko dengan loyalitas pelanggan, yaitu intensi pembelian ulang dan keinginan merekomendasikan kepada orang lain". Menurut Shabazz, Abu An-Nagary (2008) dalam artikelnya "Membangun Kepercayaan Pelanggan", kepercayaan konsumen yang diperoleh akan berakibat pada munculnya loyalitas pelanggan kepada perusahaan, di saat-saat kita dalam kondisi sulit, pelanggan datang kepada perusahaan sebagai penolong dengan tetap berbelanja produk atau jasa di perusahaan. Menurut hasil penelitian Gaunaris dan Venetis (2002), pengembangan kepercayaan pada diri konsumen berpengaruh langsung terhadap kinerja pelayanan dan keberhasilan untuk menggaet konsumen. Menurut Ravald dan Gronroos (1996), bahwa nilai yang dirasakan konsumen dapat membangun hubungan dengan konsumen, kredibilitas perusahaan, kepercayaan, dan loyalitas konsumen. 
Pengertian citra toko adalah sebagai berikut. Berdasarkan pendapat Bunne dan Lucsh (2005), yang dikutip dari Derema (Jurnal Manajemen, Vol.2, No.2, Mei 2007), menyatakan bahwa ritel adalah aktivitas-aktivitas dari tahapan yang dibutuhkan untuk menempatkan barang (goods) yang dibuat sampai ke tingkat konsumen atau menyediakan jasa ke konsumen. Sedangkan menurut Suryandari (Jurnal Bisnis dan Manajemen, Vol.3, No.2, 2003), beberapa pengertian dari dimensi dalam mengukur citra took, yaitu harga, kualitas produk, pilihan barang, lokasi, pelayanan, desain toko, fasilitas fisik, dan promosi.

Pengertian kepercayaan pelanggan adalah sebagai berikut. Menurut Costabile (Jurnal Manajemen dan Kewirausahaan, Vol.6, No.2, 2004), kepercayaan konsumen (customers trust) didefinisikan sebagai persepsi akan keterandalan dari sudut pandang konsumen didasarkan pada pengalaman, atau lebih pada urutan-urutan transaksi atau interaksi yang dicirikan oleh terpenuhinya harapan akan kinerja produk dan kepuasan. Sedangkan menurut Graham Dietzs dan Dianne N. den Hartog (Jurnal Measuring Trust Inside Organization, Personnel Riview, 2006, Vol.35, No.5), menyebutkan bahwa kepercayaan memiliki 2 bentuk konsep, yaitu: (1) "Trust is a subjective, aggregated and confident set of beliefs about the other party and one's relationship with her or him, which lead to assume that the other party's likely actions will have positive consequences for oneself'; dan (2) "Trust is the decision to actually trust the other party". Lebih jauh lagi, menurut Mayer (1995), ada 3 dimensi yang menjadi dasar penting untuk membangun kepercayaan seseorang untuk percaya pada media, transaksi atau komitmen tertentu, yaitu kemampuan (ability), kebaikan hati (benevolence), dan integritas (integrity).

Pengertian loyalitas pelanggan adalah sebagai berikut. Berdasarkan pendapat Griffin (2002) yang dikutip oleh Hurriyati (2005:129), loyalitas pelanggan adalah "Loyalty is defined as non random purchase expressed over time by some decision making unit". Berdasarkan definisi tersebut, dapat dijelaskan bahwa loyalitas lebih mengacu pada wujud perilaku dari unit-unit pengambilan keputusan untuk melakukan pembelian secara terus-menerus terhadap barang atau jasa suatu perusahaan yang dipilih. Ada 3 kriteria untuk mendefinisikan pelanggan setia (loyal), yaitu keinginan untuk membeli produk dan jasa dari perusahaan tanpa membandingkan produk atau jasa yang ditawarkan pesaing, merekomendasikan perusahaan, produk dan pelayanan perusahaan dari mulut ke mulut kepada orang lain serta tindakan pro aktif untuk memberikan saran produk atau jasa karena perusahaan.

\section{METODE PENELITIAN}

Jenis penelitian yang digunakan adalah penelitian deskiptif asosiatif. Teknik pengumpulan data dengan menggunakan kuesioner ke 100 pelanggan toko, dan model skala kuesioner adalah skala Likert. Teknik Metode analisis menggunakan beberapa Teknik, yaitu Uji Validitas, Uji Reliabilitas, Uji Normalitas, dan Analisis Jalur. Hipotesis penelitiannya adalah citra toko berkontribusi secara simultan terhadap kepercayaan konsumen. Citra toko dan kepercayaan konsumen berkontribusi secara simultan terhadap loyalitas pelanggan.

\section{HASIL DAN PEMBAHASAN}

Berikut penjabaran data hasil survei yang telah dilakukan. Untuk menguji hipotesis digunakan analisis jalur yang terbagi menjadi dua, di mana pengujian dilakukan secara keseluruhan dan individu untuk 2 struktur yang dipecah juga menjadi sub struktur 1 dan sub struktur 2. Berikut ini merupakan kerangka hubungan antar jalur (X terhadap Y, X terhadap Z, dan Y terhadap Z) dan dibuat dalam persamaan stuktural sebagai berikut: 
$\mathrm{Y}=\rho_{\mathrm{yx}} \mathrm{X}+\rho_{\mathrm{y}}{ }^{\varepsilon 1}$

$Z=\rho_{z x} X+\rho_{z y} Y+\rho_{z}{ }^{\varepsilon 2}$

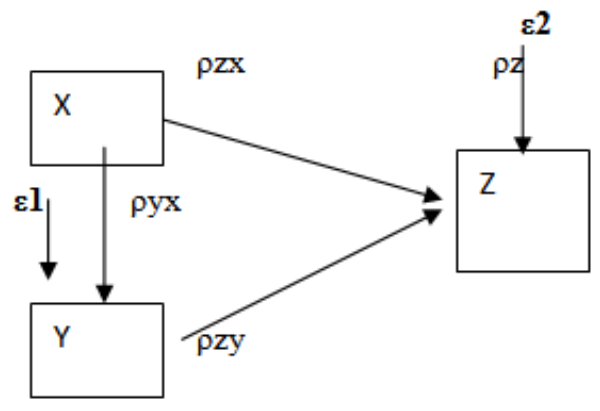

Gambar 1 Struktur hubungan X,Y dan Z.

Sumber: Ridwan \& Kuncoro (2007)

\section{Sub struktur 1 Pengujian Citra Toko terhadap Kepercayaan Konsumen}

Tabel 1 ANOVA Sub Struktur 1

ANOVA

\begin{tabular}{|c|c|c|c|c|c|}
\hline Model & $\begin{array}{l}\text { Sum of } \\
\text { Squares }\end{array}$ & df & Mean Square & $\mathrm{F}$ & Sig. \\
\hline $1 \quad$ Regressior & 7,481 & 1 & 7,481 & 37,902 &, $000^{\mathrm{a}}$ \\
\hline Residua & 19,344 & 98 & 197 & & \\
\hline Total & $26,82 €$ & 99 & & & \\
\hline
\end{tabular}

a. Predictors: (Constant), citratoko

b. DependentVariable: kepercayaankonsumer

Tabel 2 Model Summary Sub Struktur 1

Model Summary ${ }^{\text {b }}$
\begin{tabular}{|l|r|r|r|r|}
\hline Model & R & R Square & $\begin{array}{l}\text { Adjusted } \\
\text { R Square }\end{array}$ & $\begin{array}{r}\text { Std. Error of } \\
\text { the Estimate }\end{array}$ \\
\hline 1 &, $528^{\text {a }}$ &, 279 &, 272 &, 44429 \\
\hline
\end{tabular}
a. Predictors: (Constant), citratoko
b. Dependent Variable: kepercayaankonsumen

Dari Tabel Anova, diperoleh nilai $\mathrm{F}$ sebesar 37.902 dengan nilai probabilitas (signifikan) 0.000 karena nilai sig $\leq 0.05$, maka keputusannya adalah $H_{\mathrm{o}}$ ditolak dan $H_{\mathrm{a}}$ diterima. Oleh sebab itu, pengujian secara individual dapat dilakukan. Besarnya pengaruh variabel citra toko dan kepercayaan konsumen dapat diketahui dengan melihat $\mathrm{R}$ Square pada Tabel 2, bahwa $\mathrm{R}$ Square $=0.279$ atau $27.9 \%$, dan besarnya pengaruh dari variabel lain yang mempengaruhi kepercayaan konsumen sebesar 0.721 atau $72.1 \%$. Sementara itu, besar koefisien jalur bagi variabel lain di luar penelitian yang mempengaruhi nilai $\mathrm{Y}$ sebesar 0.84 . 
Tabel 3 Coefficient Sub struktur 1

Coefficients $^{a}$

\begin{tabular}{|c|c|c|c|c|c|c|}
\hline \multirow{2}{*}{\multicolumn{2}{|c|}{ Model }} & \multicolumn{2}{|c|}{$\begin{array}{l}\text { Unstandardized } \\
\text { Coefficients }\end{array}$} & \multirow{2}{*}{$\begin{array}{l}\text { Standardized } \\
\text { Coefficients } \\
\text { Beta }\end{array}$} & \multirow[b]{2}{*}{$t$} & \multirow[b]{2}{*}{ Sig. } \\
\hline & & B & Std. Error & & & \\
\hline & (Constant) & 1,769 &, 273 & & 6,482 &, 000 \\
\hline & citratoko &, 474 & ,077 &, 528 & 6,156 &, 000 \\
\hline
\end{tabular}

a. Dependent Variable: kepercayaankonsumen

Dari hasil uji signifikan pada Tabel 3. dapat diketahui nilai signifikan sebesar 0.000, maka nilai sig lebih kecil, yaitu $0.000<0.05$. Hal tersebut menunjukkan bahwa $H_{\mathrm{o}}$ ditolak, dan $H_{\mathrm{a}}$ diterima, yang artinya adalah citra toko berpengaruh secara signifikan terhadap kepercayaan konsumen.

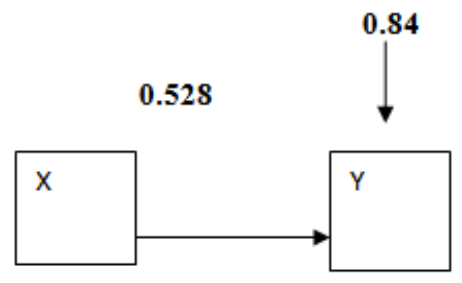

Gambar 2 Sub struktur 1 hubungan $\mathrm{X}$ dan $\mathrm{Y}$

Jadi, persamaan struktural untuk sub struktur 1 adalah:

$$
\begin{aligned}
\mathrm{Y} & =\rho_{\mathrm{yx}} \mathrm{X}+{\rho_{\mathrm{y}}}^{{ }^{\varepsilon 1}} \\
& =0.528 \mathrm{X}+0.84 \\
\mathrm{R}^{2} & =0.279
\end{aligned}
$$

Citra toko (X) mempengaruhi kepercayaan konsumen (Y) secara simultan sebesar 0.279 atau 27.9\%, dan sisanya sebesar 0.721 atau $72.1 \%$ dipengaruhi variabel lain di luar penelitian ini. Pengaruh citra toko terhadap kepercayaan konsumen secara langsung sebesar 0.528 .

\section{Sub struktur 2 Pengaruh Citra Toko dan Kepercayaan Konsumen terhadap Pengujian secara Keseluruhan Citra Toko

\begin{tabular}{|c|c|c|c|c|c|c|}
\hline \multicolumn{7}{|c|}{ ANOVA $^{b}$} \\
\hline & & $\begin{array}{l}\text { Sum of } \\
\text { Squares }\end{array}$ & df & Mean Square & $\mathrm{F}$ & Sig. \\
\hline \multirow[t]{3}{*}{1} & Regressior & $27,24 \mathrm{G}$ & 2 & 13,625 & 1230,399 &, $000^{a}$ \\
\hline & Residua & 1,074 & 97 &, 011 & & \\
\hline & Total & 28,323 & 99 & & & \\
\hline
\end{tabular} dan Kepercayaan Konsumen terhadap Loyalitas Pelanggan}

Tabel 4 ANOVA Sub struktur 2

a. Predictors: (Constant), kepercayaankonsumen, citratokc

b. Dependent Variable: loyalitaspelanggan 
Tabel 5 Model Summary Sub struktur 2

Model Summary
\begin{tabular}{|l|r|r|r|r|}
\hline Model & R & R Square & $\begin{array}{r}\text { Adjusted } \\
\text { R Square }\end{array}$ & $\begin{array}{r}\text { Std. Error of } \\
\text { the Estimate }\end{array}$ \\
\hline 1 &, $981^{\text {a }}$ &, 962 &, 961 &, 10523 \\
\hline
\end{tabular}
a. Predictors: (Constant), kepercayaankonsumen, citra toko
b. Dependent Variable: loyalitaspelanggan

Besarnya pengaruh variabel citra toko dan kepercayaan konsumen terhadap loyalitas pelanggan dapat diketahui dengan melihat $\mathrm{R}$ Square pada Tabel 5, bahwa $\mathrm{R}$ Square $=0.962$ atau $96.2 \%$, dan besarnya pengaruh dari variabel lain yang mempengaruhi loyalitas pelanggan sebesar 0.38 atau 3.8\%. Sementara itu, besar koefisien jalur bagi variabel lain di luar penelitian yang mempengaruhi nilai $Y$ dapat dihitung melalui rumus sebagai berikut, $Z=\rho_{z x} X+\rho_{z y} Y+\rho_{z}{ }^{\varepsilon 2}=0.19$.

\section{Pengujian Secara Individual Citra Toko dan Kepercayaan Konsumen terhadap Loyalitas Pelanggan}

Pertama, citra toko (X) berpengaruh secara signifikan terhadap loyalitas pelanggan (Z).

Tabel 6 Coefficient Sub struktur 2

Coefficients $^{\mathrm{a}}$

\begin{tabular}{|c|c|c|c|c|c|c|}
\hline \multirow{2}{*}{\multicolumn{2}{|c|}{ Model }} & \multicolumn{2}{|c|}{$\begin{array}{c}\text { Unstandardized } \\
\text { Coefficients }\end{array}$} & \multirow{2}{*}{$\begin{array}{c}\text { Standardized } \\
\text { Coefficients } \\
\text { Beta }\end{array}$} & \multirow[b]{2}{*}{$\mathrm{t}$} & \multirow[b]{2}{*}{ Sig. } \\
\hline & & $\mathrm{B}$ & Std. Error & & & \\
\hline & (Constant) &, 265 &, 077 & & 3,433 &, 001 \\
\hline & citratoko &, 043 &, 021 & 047 & 2,020 &, 046 \\
\hline & kepercayaankonsumen & ,981 & 024 & ,955 & 41,023 &, 000 \\
\hline
\end{tabular}

a. DependentVariable: loyalitaspelanggan

Dari hasil uji signifikan pada Tabel 6, dapat diketahui nilai signifikan sebesar 0.046, maka nilai sig lebih kecil, yaitu $0.046<0.05$. Hal tersebut menunjukkan bahwa $H_{\mathrm{o}}$ ditolak dan $H_{\mathrm{a}}$ diterima, yang artinya citra toko berpengaruh secara signifikan terhadap loyalitas pelanggan.

Kedua, kepercayaan konsumen (Y) berpengaruh secara signifikan terhadap loyalitas pelanggan $(Z)$. Dari hasil uji signifikan pada Tabel 6, dapat diketahui nilai signifikan sebesar 0.000, maka nilai sig lebih kecil, yaitu $0.000<0.05$. Hal tersebut menunjukkan bahwa $H_{\mathrm{o}}$ ditolak dan $H_{\mathrm{a}}$ diterima, yang artinya kepercayaan konsumen berpengaruh secara signifikan terhadap loyalitas pelanggan.

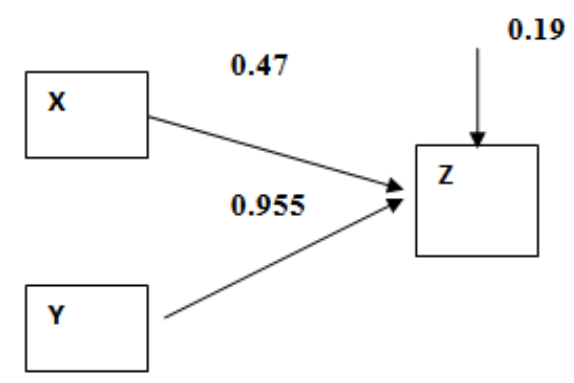

Gambar 3 Sub struktur 2 Hubungan X,Y dan Z 
Jadi, persamaan struktural untuk sub struktur 2:

$$
\begin{aligned}
\mathrm{Z} & =\rho_{\mathrm{zx}} \mathrm{X}+\rho_{\mathrm{zy}} \mathrm{Y}+\rho_{\mathrm{z}}{ }^{{ }^{2} 2} \\
& =0.47 \mathrm{X}+0.955 \mathrm{Y}+0.19 \\
\mathrm{R}^{2} & =0.962
\end{aligned}
$$

Citra toko (X) dan kepercayaan konsumen (Y) secara simultan mempengaruhi loyalitas pelanggan sebesar 0.962 atau $96.2 \%$, dan sisanya sebesar 0.38 atau 3.8\% dipengaruhi variabel lain di luar penelitian ini. Pengaruh citra toko terhadap loyalitas pelanggan secara langsung sebesar 0.47 , dan pengaruh kepercayaan konsumen terhadap loyalitas pelanggan secara langsung sebesar 0.955 . Dengan ini, berarti analisis sub struktur 1 dan sub struktur 2 telah selesai, maka dapat digambarkan struktur hubungan secara lengkap, yakni hubungan antara variabel $\mathrm{X}, \mathrm{Y}$, dan $\mathrm{Z}$ yang memiliki persamaan struktural:

$$
\begin{aligned}
& \text { Persamaan sub-struktur 1: } \quad \mathbf{Y}=\mathbf{0 . 5 2 8 X}+\mathbf{0 . 8 4} \\
& \text { Persamaan sub-struktur 2: } \quad \mathbf{Z}=\mathbf{0 . 4 7} \mathbf{X}+\mathbf{0 . 9 5 5} \mathbf{Y}+\mathbf{0 . 1 9} \\
& \varepsilon 20.19
\end{aligned}
$$

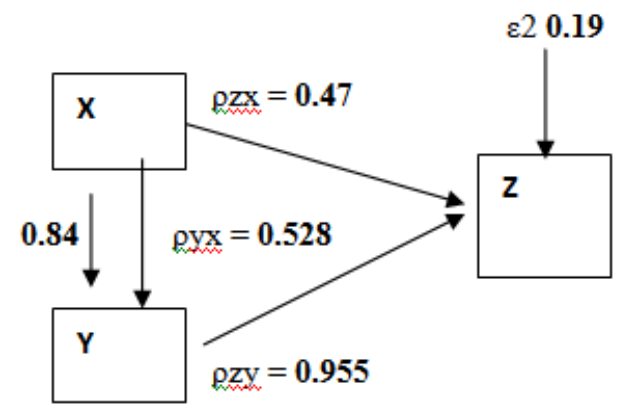

Gambar 4 Struktur Lengkap Hubungan X, Y dan Z

Tabel 7 Rangkuman Pengaruh X, Y, Z

\begin{tabular}{ccccc}
\hline Pengaruh & Koefisien & \multicolumn{2}{c}{ Pengaruh } & \multirow{2}{*}{ Total } \\
\cline { 3 - 4 } Variabel & Jalur & Langsung & Tidak Langsung & \\
\hline $\mathrm{X}-\mathrm{Y}$ & 0.528 & 0.528 & - & 0.528 \\
$\mathrm{X}-\mathrm{Z}$ & 0.47 & 0.47 & 0.528 & 0.248 \\
$\mathrm{Y}-\mathrm{Z}$ & 0.955 & 0.955 & - & 0.955 \\
\hline
\end{tabular}

Jadi, hasil keseluruhan pengaruh variabel citra toko (X) terhadap kepercayaan pelanggan (Y) serta dampaknya terhadap loyalitas pelanggan ( $Z$ ) adalah sebagai berikut. Pertama, citra toko mempengaruhi kepercayaan pelanggan sebesar $(0.528)^{2}=0.2788$ atau $27.88 \%$, dan sisanya sebesar $72.12 \%$ dipengaruhi oleh variabel lain di luar penelitian ini. Kedua, citra toko secara langsung mempengaruhi loyalitas pelanggan sebesar $(0.47)^{2}=0.2209$ atau $22.09 \%$, dan sisanya sebesar $77.91 \%$ dipengaruhi oleh variabel lain di luar penelitian ini. Ketiga, citra toko secara tidak langsung mempengaruhi loyalitas pelanggan sebesar $(0.528)^{2}=0.2788$ atau $27.88 \%$, dan sisanya sebesar $72.12 \%$ dipengaruhi oleh variabel lain di luar penelitian ini. Keempat, kepercayaan konsumen mempengaruhi loyalitas pelanggan sebesar $(0.955)^{2}=0.912$ atau $91.2 \%$, dan sisanya sebesar $8.8 \%$ nilai variabel loyalitas pelanggan dipengaruhi oleh variabel lain. 


\section{SIMPULAN}

Untuk mengukur loyalitas pelanggan melalui citra toko dan kepercayaan pelanggan diperoleh hasil bahwa Citra toko dan kepercayaan konsumen berpengaruh secara simultan dan signifikan terhadap loyalitas pelanggan. Dilihat secara individual kepercayaan pelanggan lebih besar pengaruhnya terhadap loyalitas pelanggan dibandingkan citra toko.

\section{DAFTAR PUSTAKA}

Anonymous. (2007). Membangun kepercayaan dengan kedekatan, Diakses dari www.sinarharapan.co.id.

Dietz, G., and Deanne. N., and Dean, H. Measuring trust inside organizations. Retrieved September 25,2009 , from http:www.emeraldinsight.com.insight.viewcontentservletFilename=publishedemeraldfuultexta rticle.pdf0140350504.pdf.

Djati, P. (2004). Pentingnya karyawan dalam pembentukan kepercayaan konsumen dalam perusahaan jasa. Jurnal Ekonomi Manajemen, Vol.6, No.2, September, p.114-122. Retrieved September 27, 2009, from http://puslit.petra.ac.id/journalis/management.

Graffin, J. (2005). Customer loyalty: Menumbuhkan dan mempertahankan kesetiaan pelanggan, edisi revisi dan terbaru, Jakarta: Penerbit Erlangga.

Hasan, A. (2008). Marketing, Yogyakarta: Medpress.

Hurriyati, R. (2005). Bauran pemasaran dan loyalitas konsumen, Bandung: CV Alfabeta.

Indriantoro, N., dan Supomo, B. (2002). Metode penelitian bisnis: Untuk akuntansi dan manajemen, edisi pertama, Yogyakarta: BDFF.

Iskandar, A., dan Bernato, I. (2007). Pengaruh kualitas pelayanan restoran platinum lippo karawaci terhadap loyalitas pelanggan. Derema Jurnal Manajemen, Vol.2, No.2. Diakses tanggal 23 September 2009, dari http://bs.uph.ac.id/research-a-publication/journal-a-publication/76Derema4.html.

Kotler, P. (2003). Marketing management, $11^{\text {th }}$ ed., New Jersey: Pearson Education, Inc.

Kotler, P., dan Armstrong, G. (2008). Prinsip-prinsip pemasaran, edisi keduabelas, jilid pertama, Jakarta: Erlangga.

Ma’ruf, H. (2006). Pemasaran ritel, Jakarta: PT Gramedia Pustaka Utama.

Peter, J.P., dan Olson, J.C. (2000a). Consumer behavior: Perilaku konsumen dan strategi pemasaran, jilid pertama, edisi keempat. Versi Bahasa Indonesia, Jakarta: Erlangga.

Peter, J.P., dan Olson, J.C. (2000b). Consumer behavior: Perilaku konsumen dan strategi pemasaran, jilid pertama, edisi keempat. Versi Bahasa Indonesia, Jakarta: Erlangga. 
Priyono, H. (2008). Hubungan antara citra toko dengan loyalitas konsumen. Diakses tanggal 20 September 2009, dari http://etd.eprints.ums.ac.id/1849.

Riduwan dan Kuncoro, E.A.. (2007). Analisis jalur (path analysis), Bandung: Alfabeta.

Sarwono, J. (2006). Metode penelitian kuantitatif dan kualitatif, edisi pertama, Yogyakarta: Graha Ilmu.

Sarwono, J. (2007). Analisis jalur untuk riset bisnis dengan SPSS, Yogyakarta: ANDI.

Sekaran, U. (2006). Metodologi penelitian untuk bisnis, edisi keempat, Jakarta: Salemba Empat.

Schiffman, L.G, dan Leslie, L.K. (2007). Perilaku konsumen, edisi ketujuh, Jakarta: PT Indeks.

Shabazz, A.A. (2008). Membangun kepercayaan konsumen. Diakses tanggal 25 September 2009, dari http://annagry.wordpress.com/category/manajemen.

Sophiah dan Syihabudhin. (2008). Manajemen bisnis ritel, Yogyakarta: ANDI.

Sugiyono. (2007). Metode penelitian bisnis, Bandung: CV Alfabeta.

Suryandari, R.I., dan Retno, T. (2009). Analisis pengaruh citra supermarket terhadap loyalitas konsumen. Jurnal Bisnis dan Manajemen, Vol.3, No.2. Diakses tanggal 15 Oktober 2009, dari

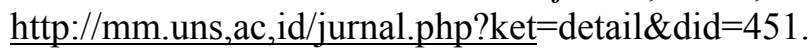

Tjiptono, F. (2002). Strategi bisnis, Yogyakarta: ANDI.

Umar, H. (2003). Metode riset bisnis, Jakarta: PT Gramedia Pustaka Utama.

Umar, H. (2005). Riset pemasaran dan perilaku konsumen, Jakarta: PT Gramedia Pustaka Utama.

Utami, C.W. (2006). Manajemen ritel: Strategi dan implementasi ritel modern, Jakarta: Salemba Empat. 